\title{
TOURISM MARKETING: CONTEXT, CHALLENGES AND POTENTIAL
}

\author{
Rety Palupi ${ }^{1}$, Mincho Slavov ${ }^{2}$ \\ ${ }^{1}$ Email: rety.ryp@bsi.ac.id \\ Faculty of Communication and Language, Bina Sarana Informatika University \\ ${ }^{2}$ Email: mslavov@protonmail.com \\ Faculty of Law and History, South-West University N. Rilski, Bulgaria
}

\begin{abstract}
Abstrak: Saat ini, pariwisata adalah salah satu sektor ekonomi yang terkemuka dan paling dinamis dan karena kemampuannya yang berubah secara cepat, pariwisata diakui sebagai fenomena ekonomi pada abad ini. Marketing dalam industry pariwisata menjadi semakin penting untuk daya saing global. Dalam konteks ini, penelitian ini bertujuan untuk menganalisis dan meneliti mengenai tantangan yang dihadapi dalam marketing di industry pariwisata modern. Pendekatan yang diambil dalam makalah ini adalah untuk menilai literasi yang terkait dan fokus pada poin-poin penting untuk penelitian di masa yang akan datang tentang marketing di industri pariwisata. Marketing di industry pariwisata ini harus mengarah pada optimalisasi pada dampak pariwisata serta pencapaian sasaran strategis organisasi pariwisata nasional. Makalah ini memberikan kontribusi kepada para marketer bidang pariwisata dan juga akademisi, untuk menunjukkan keunikan marketing pada industry pariwisata.
\end{abstract}

Abstract: Tourism is one of the leading and most dynamic sectors of the world economy, and for its rapid pace, it is recognized as the economic phenomenon of the century. Modern tourism is an increasingly intensive, business-oriented, and commercially organized group of activities, and tourism marketing is becoming ever more important for a destination's competitiveness. In this context, our research aims to analyze and synthesize the challenges marketing of tourist destinations is facing. The approach taken in this paper is to assess the related literature and focus on the key points for future research on tourism marketing. We argue that destination marketing must lead to the optimization of the effects of tourism and the achievement of national tourism organizations' strategic goals. This paper contributes to marketing professionals and academics, pointing out the uniqueness of tourism marketing.

Keywords: tourism, marketing, tourism development, destination marketing.

\section{INTRODUCTION}

Within the framework of modern conditions, tourism tops the list of the world economy's most critical socio-economic sectors. With the growth and constant change in the tourist market, competition is extremely high. In the face of increased rivalry, companies are forced to focus on meeting the customers' needs. That is why the travel industry needs a growing number of marketing professionals who understand its global challenges and respond to clients' growing needs by developing creative strategies based on expert marketing knowledge (Phillip Kotler et al. 2017). Close coordination of marketing of various organizations and enterprises is needed to achieve a positive marketing effect. Therefore, the concept of marketing in tourism is more than anywhere else, holistic and comprehensive (Font and McCabe 2017).

In its main characteristics, tourism does not have fundamental differences from any other form of economic activity. Therefore, all the essential provisions of modern marketing can be fully applied in tourism. At the same time, tourism has its specificity, distinguishing it not only from trade in goods but also trade in services, as well as the unique nature of consumption of tourist services and goods in the place of their production, moreover, in a particular situation (M. Kotler et al. 2020). In traditional production, which has a specific result of labor (a product), the concept of marketing has more specific content. In tourism, the result of the activity is reduced to a tourist product. A tourist product is any service 
that meets tourists' particular needs and is payable on their part.

The main tourist product is a comprehensive service, a standard set of services sold to tourists in one package. First, the demand for tourism services is exceptionally elastic concerning income and prices, but it also depends on political and social conditions. Secondly, due to seasonal fluctuations in demand, there is a so-called saturation phenomenon. As a result, welldefined tourist zones can be identified. Thirdly, the offer of tourist services is limited production. They can only be consumed directly on the spot. Fourth, the tourist product is created by many enterprises' efforts, each with its working methods, specific needs, and various commercial goals. Fifthly, the high quality of tourist services cannot be achieved if there are minor drawbacks, as the same service of tourists consists of these tiny things and small details (So and Morrison 2004).

These specific features of the tourist product have a significant impact on marketing in tourism. As there is no unambiguous definition of marketing in general, so there is no single tourism marketing interpretation (Truong and Hall 2017). However, this concept can be interpreted as follows: marketing in tourism is a system of continuous alignment of the services offered with services in demand in the market, and which the tourist company can offer profitably for themselves and more effectively than competitors do (Labanauskaite, Fiore, and Stašys 2020).

The advent of the new technologies prompted many researchers to point out the utmost importance of influencing travel decisions. Considering the intangible nature of tourism, marketers rely heavily on visual imagery to promote destinations. Virtual reality (VR), as a new form of interaction with the environment, has a great potential for destination promotion because of the immersive experience and sensation that offer and its unique abilities to communicate how a certain place looks and feels. As a marketing tool, VR can greatly reduce the perceived risk of intangible services, thus, helping travelers make an informed decision with realistic expectations of the destination (Zuelow 2015; Philip Kotler 2018).

Currently, modern tourism is an integral part of a person's socio-economic activity and is a whole complex of various phenomena, events, and relationships. Several factors are contributing to the intensive development of modern tourism:

1. Increase in household income;

2. Existence of annual paid holidays;

3. Development of the transport industry and ease of mobility;

4. Development of information and communication technologies;

5. Development of social media platforms.

These factors are the expansion of online marketing applications, including Airbnb, Booking.com, and Couchsurfing. In 2018 Airbnb's direct economic impact, based on host income and estimated guest spending worldwide, is reaching USD 100 billion and the company's revenue is USD 3.6 billion (Figure 1). Airbnb disrupted the traditional corporate business models associated with accommodation by offering a peer-to-peer marketplace. This new phenomenon is neatly related to the increased usage of the internet and mobile technologies development. Hence, the extensive use of digital marketing applications in tourism (such as Airbnb and Booking.com), related to the direct short-term rental services within the sharing economy of tourism provides a significant source of income to homeowners, which otherwise will struggle to compete with established hotel chains (Guttentag et al. 2018; Mariani et al. 2018). 
Figure 1. Airbnb's direct economic impact, 2018

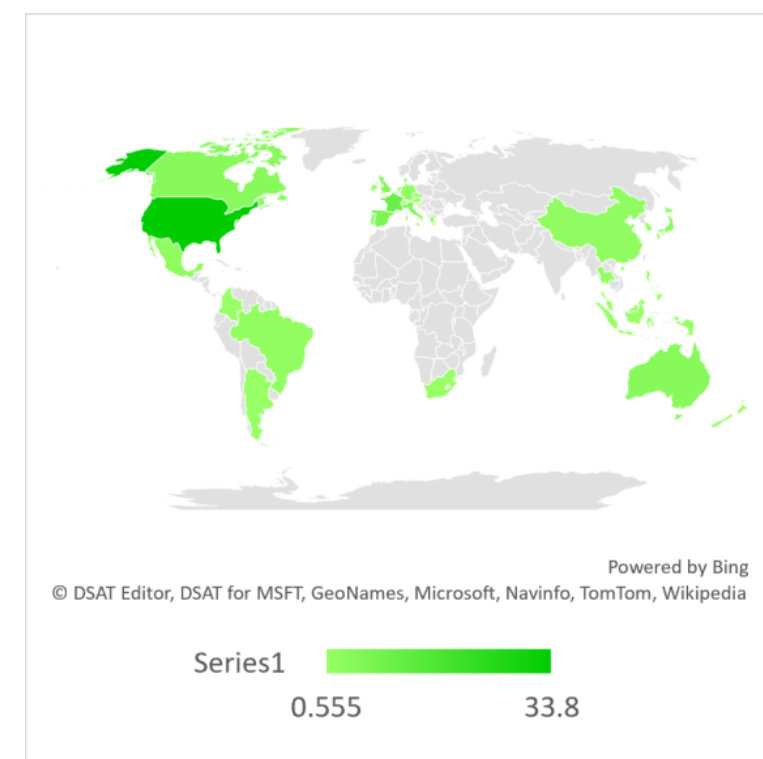

Source: Authors, data from news.airbnb.com 2019.

Tourism marketing is a system of management and organization of tourism companies to develop new, more efficient types of tourist and leisure services, produce and market them in order to make a profit by improving the quality of the tourist product and taking into account the processes that take place in the world tourist market. The organization of marketing activities in the tourism sector is conditioned by the line of enterprises in the tourism services sector to meet the rapidly changing needs of consumers in the tourist product, while, at the same time, promptly introducing modern new technologies into the tourism industry. Tourism marketers should focus on the successful solution of the main tasks: increasing the flexibility of tourist services, rapidly changing the range of tourist products following the consumer's needs, and. Yet, it is still widely believed that a destination is a product like any other and should be marketed. At the macro level, this understanding is acceptable, and marketing tools can be used, indeed. However, it is much more complicated to manage a destination because of its distinguishing features.

This research aims to review the distinctiveness of marketing in the tourism industry. To reveal the uniqueness of tourism marketing is necessary to elaborate on the following tasks:

1. Examining the content and concept of marketing in tourism;
2. Examining the tourism product as an object of tourism marketing;

3. Analyzing the market for tourist services;

Concerning the degree of study of this problem, it should be noted that having originated in the production sphere, marketing for a long time did not find appropriate tourism applications. However, the increase in competition and the commercialization of tourist activities led to the need for the earliest possible introduction of the essential elements of marketing in tourist enterprises' practice. At the same time, tourism has certain features associated with the nature of the services provided, the forms of sales, the nature of labor, etc. due to this, marketing in tourism has several characteristic features that even set it apart as a separate area of marketing as a science and academic discipline.

Marketing activity in tourism today is a dynamically developing and most promising area of an enterprise's commercial activity. The current market saturation level does not allow achieving the desired level of sales without information support for its products. Even the best product with excellent performance cannot be competitive enough without the prior preparation of consumers. Therefore, at present, marketing relevance in tourism is beyond doubt, playing a pivotal role in developing a market economy. 


\section{METHODOLOGY}

To answer the above-stated research questions, the authors chose to employ a qualitative case study approach (Harrison, Birks, Franklin, \& Mills, 2017; Merriam \& Tisdell, 2016; Tetnowski, 2015). Case studies are an adequate and appropriate in-depth investigation method, when complicated phenomena, as Tourism Marketing, is under study. Authors performed the data gathering through a comprehensive analysis of related tourism development policies and practices adopted on a national and international level. The technique was finding, selecting, understanding and synthesizing information from the documents. The documents that were analysed were mainly researchers' papers, online articles, organisational and institutional reports and books.

\section{RESULTS AND DISCUSSION}

The term "marketing" means market activity, work with the market. Marketing is a manageable social process through which individuals and groups of people acquire what they need and want to get by exchanging with other created products and values (Gretzel 2018). Marketing includes:

1. Determining the needs, queries, and needs of buyers;

2. Develop and market the products that buyers need and can meet their needs;

3. Setting prices acceptable to buyers and providing sufficient profit to the seller;

4. Choosing the most profitable and convenient ways to bring goods to consumers;

5. Justifying and using methods and means of active influence on the market to generate demand and stimulate sales.

Each of these areas is important in itself. However, each of them's value and significance is most important when they are considered and exercised in unity and integrity. In this case, they talk about the implementation of the concept of marketing.

The concept of marketing has spread in many areas of human activity:

1. Marketing of consumer goods;

2. Marketing of manufacturing products;

3. Marketing of capital construction facilities;

4. Marketing services etc.

Different types of marketing have a general methodology, but the content and specific implementation of the marketing concept depend on the nature of the enterprise and the nature of the product on offer. Services, in particular the tourism sector, have four characteristics that affect the organization of marketing in the enterprise:

1. Inconsistency, inviolability, or intangible nature of services means that they cannot be demonstrated, seen, tried, transported, stored, packaged, or explored before receiving these services;

2. The inseparability of the production and consumption of the service. The specificity of the production of services is that, unlike goods, services cannot be produced and stored. The tourism firm can provide the service only when an order arrives or a customer appears.

3. The inevitable consequence of the simultaneous production and consumption of the service is the variability of the service. The quality of the service depends heavily on who provides it and where and when it is provided (for example, the same employee can provide the service in different ways).

4. An essential feature of services is their "momentariness." Services cannot be stored for further sale and delivery. If the demand for services becomes more significant than the supply, then this cannot be corrected, as in industry, by taking goods from the warehouse. Similarly, if services' capacity exceeds the demand for them, it loses income and (or) the cost of services.

Marketing has been used in the tourism business only since the 1950s (Zaenal, Kamase, and Serang 2020; Ali, Amin, and Priansah 2019). Marketing in tourism is a product of the collective creativity of entrepreneurs from different countries. At each stage of the development of market relations, a unique approach to commercial activity in tourism was formed. Historically, the so-called production concept was the first to emerge. Tourism companies in the 1950 s widely used it. It was during this period that the demand for tourist services far exceeded the supply.

Therefore, almost all tourist services were on the market, sold immediately, even if they did not fully meet the requirements that consumers made: the main thing - their availability, quantity, and quality paid minimal attention. Tourism firms offered almost identical products; there was no competition in 
the market. As a result, the consumer was forced to purchase what was offered to him. All the attention of tourism firms focused on domestic production opportunities to saturate the market with their services (Majed Sadq and Khorsheed 2019). Tourism marketing has been used to stimulate demand for tourism services.

The concept of intensifying commercial efforts already involves maximizing sales through advertising and promotional measures. In the early 1960s, the first signs of a change in the tourist market's supply-demand relationship began to appear (Lumsdon 2016; Cuculeski, Petrovska, and Cuculeski 2016). Competition has escalated. In this situation, firms began to focus on the problems of marketing their services. By the mid-70s in the tourism sector formed a buyer's market. Under the current conditions, working for an unknown or littleknown market did not give the tourist company any guarantees regarding services' marketing. To ensure success in the competition, it was necessary first to carefully study the market and offer services that meet the market requirements. At the same time, tourism companies adapted to the requirements of the market and formed the consumer's needs. This phase is already characterized as a marketing concept in tourism - this concept argues that the key to achieving the goals of the organization is to determine the needs and needs of target markets and to ensure the desired satisfaction in more efficient and more productive ways than those of competitors (Sofronov 2019).

The marketing process begins with an analysis of market opportunities. A set of market research solves this task. The result is an analysis of the actual situation and specific recommendations to determine the company's prospects, taking into account the most attractive investment areas (Kim and Chae 2018). By comparing identified market opportunities with the company's goals and resources, its marketing capabilities are highlighted. Such an approach allows the company not to spray marketing efforts, work on the whole market, and focus on meeting the needs of selected groups of customers, which the company can serve. This is ensured by choosing the optimal marketing strategy. This reduces the degree of uncertainty and risk in marketing activities and ensures that resources are concentrated on selected priority areas. The chosen strategy is specified in the programs
(Labanauskaitè, Fiore, and Stašys 2020; Lim, Yap, and Makkar 2021).

The practical implementation of the marketing strategy is related to the choice of tools that will materialize the goals and objectives. Therefore, the most important place in marketing activity is the development of the marketing complex. It is a combination of influencing consumers of the target market to cause them the desired response.

The marketing complex's main elements are product, price, marketing, and communications (Seyfi and Hall 2020). Given the critical importance of complex marketing as part of a general marketing strategy, private strategies are being developed for all its core elements:

1. Product strategy

2. Price strategy

3. Marketing strategy

4. Communication strategy.

The product strategy involves developing a tourist product that is most appropriate to tourists' needs, the development and introduction of new tourism services to the market. The marketing strategy includes identifying channels, forms, and methods of bringing the tourist product to the consumer. These activities include advertising, promotion, personal sales, promotion, exhibition events, and forming a corporate identity.

To ensure the effectiveness of marketing management requires the development of its support systems:

1. Marketing information

2. Marketing organizations

3. Marketing control.

The marketing information system ensures that information is obtained, organized, evaluated, and used to characterize the state of the tourist company's external and internal environment. Without objective, relevant, and sufficiently complete marketing information, it is impossible to make operational and strategic decisions (Seyfi, Hall, and Vo-Thanh 2020). A marketing control system is created to monitor the implementation of marketing strategies and programs regularly. In practice, the technology of implementing the concept of marketing is very elastic. It can change both its structure and the place of individual stages depending on the company's characteristics, the degree of market development, the goal, objectives, and market conditions. 
However, all these elements are interconnected. None of them can be excluded from the system without violating their integrity.

The success of commercial activities in the tourism market is determined, first of all, by an attractive tourist product. The term "product" reflects the quality or essence of specific abstract things (food prepared by a restaurant chef or a guide introducing a tourist to a given area or museum). However, the tourist product at the same time is a collection of very complex heterogeneous elements:

1. Natural resources (air, water, sun, landscape, etc.), historical, cultural, architectural attractions that can attract tourists and encourage them to travel;

2. Equipment - accommodation facilities for tourists, restaurants, equipment for recreation, and sports, which in itself is not a factor influencing the motivation of travel, but in the absence of it, there are numerous obstacles to possible travel;

3. Mobility opportunities, which, to a certain extent, depending on the fashion for various types of transport used by tourists.

In most cases, the tourist product is the result of the efforts of many companies. Marketing in tourism is aimed at studying the aggregate product of various fields of activity. It also adds the information links needed to compromise better customer satisfaction and big profits for stakeholders and owners (Lumsdon 2016).

Until a certain point, a tourist product has absolutely no value for the consumer. People do not buy goods on the market, but their functional ability to satisfy a particular human need. So, a tourist pays not for hotel accommodation but new sensations and acquaintances with the unknown, not for a steak, but the pleasure of it (Antalova et al. 2019). Only by realizing that a product can satisfy some critical need does a person become a buyer. Marketing aims to direct the goods people need to a specific place at an affordable price. Implementation of the tourist company's market interest to its product predetermines the need to study its consumer qualities and properties thoroughly to identify its most attractive sides for tourists.

A tourist product is any service that meets tourists' needs when traveling and is payable on their part. In practice, the concept of primary and basic services applies. However, in terms of consumer properties, there are no significant differences between them. Thus, excursions included in the complex service are considered an essential service, but if a tourist buys them independently (on his own) at the place of stay, they already become additional (Dudyak et al. 2018). Therefore, the difference between basic and additional services lies in their relationship to the tourist services package purchased initially by the tourist. In practice, the main tourist product is a comprehensive service - a standard set of services sold to tourists in one "package."

By analogy with goods that have a material form, there are three different levels in the tourist product:

1. Product by design;

2. Real-world product;

3. Product with reinforcement.

At the heart of any tourism product is the need to meet and satisfy a particular need. Therefore, the core of the product, its essential side, is the so-called concept: its focus on solving a particular problem and meeting a specific need. It does not acquire a product, as such, having a specific set of properties, but its ability to satisfy some of its needs (Dudyak et al. 2018). Consequently, it is of great importance for a tourist company to present and disseminate not the properties of its product but the real benefits and benefits of it for its client. If the concept of a tourist product acts as its content side, then in terms of its form, a tourist product in real performance is precisely a particular set of properties that make it possible to realize this concept, satisfying a particular need of the client (Dedeoğlu et al. 2020). Therefore, at the second level of a tourist product, its properties and characteristics are considered: quality level, comfort, prestige, economy, safety, impression, etc.

The third level is a tourist product with reinforcement. A tourist enterprise's activities should be aimed at forming friendly relations with the client, providing him with comprehensive assistance, additional and symbolic benefits. This can be achieved through a high quality and speed of service, advice, information, and informal communication (Philip Kotler, Bowen, and Makens 2014). The reinforcement of the tourism product dramatically contributes to finding and retaining customers. Thus, the quality of service is determined by: 
1. The efficiency of work on the selection and organization of tours at the request of clients;

2. Staff's hospitality, their attention to the client's requests, and patience;

3. Correspondence of the proposed tour to the real content;

4. Availability of coordination of all components of complex service.

5. The speed of service in the complex determines the degree of satisfaction of each client:

6. Timing of route selection;

7. The terms of registration of the necessary documents (passport, visa, tickets, etc.);

8. The timing of obtaining reference information.

Even though information services are provided free of charge, it is thanks to them that tourism firms primarily ensure their tourist product. Catalogs, prospectuses, brochures, and information sheets are usually used to inform consumers, detailing the package's content and quality, prices, etc. These materials should be provided to every customer who has stated his desire to purchase a particular tour. Besides, the consumer should receive additional information and advice on the order of booking, payment, change, and cancellation of the tour, as well as all other issues (passport, visa, customs, and currency regulation, nature and climate features, medical care, insurance, etc.) related to the tourist trip. The availability of information material, its knowledge of the tourist company staff, and free presentation at the tourist's request is an absolute requirement to create a tourist product and its successful implementation in the market (Philip Kotler, Bowen, and Makens 2014).

The idea of backing up a tourist product requires a close look at the customer's behavior system, how he comprehensively approaches the problem, which he tries to solve by purchasing a tourist product. From the perspective of competition, this approach allows the tourist company to identify opportunities to efficiently support its product offer.

"New competition" is not a competition among products and services offered by tourism firms, but among what they additionally supply their products in the form of specific services, consultations, bits of advice, information, features of service, and other valuable information. Therefore, travel companies must continuously look for effective ways to reinforce and make their products offered to the market more attractive (Dedeoğlu et al. 2020).

The process of globalization of demand in tourism also provokes corresponding behavior of supply. Traced by the marketing complex elements, the data show that supply is characterized by increasing standardization in the field of the product design, the main versions of the product, the marketing, the construction concepts of marketing communications.

Discussions on standardization and differentiation subsided after arguing that they are not alternative and that standardization is acceptable to the conditions of globalization and differentiation to the conditions of internationalization. Internationalization and globalization are not mutually exclusive processes. They are two basic strategies based on different market presence objectives. Namely, in the conditions of globalization of the tourist market, tourism today relies on marketing as the only way the tourist products offered in the destination are realized on the tourist market.

New challenges in tourism marketing raise several questions: how many tourists, what services are they looking for, at what time, at what prices, in which destinations, and how can their potential be activated? The orientation to the client is not a sufficient condition to maintain competitive positions. Tourism marketing requires the creation of competitive destinations and management accordingly them as competing units. Marketing has currently mastered a rich arsenal of scientifically substantiated concepts, principles, models, and methods. Today, the challenges facing professionals in the field of tourism marketing destination level are numerous, but can be synthesized in the following main directions:

1. Marketing of an integrated tourist product at the regional level. Tourism marketing aims at economic benefits and specific development of the regional economy. He creates, manages, and applies techniques through which potential customers to be provoked, informed, and motivated to visit a particular landmark, city, district, country. To achieve these results, each municipality, resort, district, or state must develop its tourist infrastructure and, yes, combine its natural, historical, and cultural resources into a tourist product. To become 
an attraction, they must have a certain set of natural and anthropogenic tourist resources. Competitiveness and attractiveness are the main requirements for any destination with claims to attract tourists. Next is creating a quality advertising and promotional campaign to impose a certain tourist brand, yes, create awareness and loyalty of the audience. The main catalyst of a successfully developed tourism industry is emotion and the experience - what attracts tourists and makes them visit a country, region, city, landmark, etc. Accommodation and nutrition are a consequence, not a root cause. Hotels and restaurants complement the specific atmosphere and take it into account, not the opposite.

2. Creating specific and unique characteristics of tourist products. Tourism products depend on many factors and the environment. On the one hand, the tourist product depends on the location, incl. tourist accessibility and the specific atmosphere created by the combination of the structural determinants factors of tourism - resources, products, customers. On the other hand, tourist services depend on customers' very participation in product structures, their interaction with the service system, and the interaction of the customers during product consumption. The product structures of tourism express different combinations of its determining components - resources, base, staff, and markets. In a complete form, they represent different types and forms of tourism.

3. Packaging of attractions and imposing a destination as attractive for tourism. This is done based on information obtained after their inventory and evaluation. The main stages are: gathering information and describing all the attractions in the region, expert assessment of their resource capacity; developing a common strategy and plan for the development of the destination, based on their potential for future development, construction and improvement of infrastructure, selection of modern means of communication for the promotion of the sights on separately for the specific destination, as well as for the region and the overall tourist product, communication, and promotion of the tourist product of the destination. In practice, there are two ways to properly package attractions - natural grouping and thematic grouping. Attractions that are not particularly attractive in themselves can be grouped with other similar attractions to create a prime attraction. That way, not only increases the attractiveness but reduces the cost of marketing and increases tourists' choices. In the thematic grouping, one image is created, which is imposed on the whole attraction. The thematic of an area is not achieved only with the creation of parks. An entire community can acquire its own identities, such as a restored one village or characteristic area. The idea of thematic grouping is unique. At the base, The process is to create a unique image that can be maintained throughout the destination.

4. Profiling and thematization of the tourist destination. The clear profile is extremely important for the competitiveness of the tourist destination, i.e., to be observed in a saturated market for tourist services should be identifiable and profiled. The main accents are identity, authenticity, and image. This from his party attracts potential visitors, evokes a positive image, motivates to revisit, makes tourists recommend it, and visits again and again, turning them into loyal customers.

5. Building a strong tourism brand through intensive marketing communications. The brand idea is a unique combination of perceptions of a destination and the type of vacation it offers, not just a "brand" imposed on the market. This is not just a matter of financial investment. Branding is not a one-time act and requires a constant transition from rational-focused branding to emotionally-focused branding. Emotional branding is valid in full force, especially in tourism, where visitors to tourist sites are positive about rest and pleasant experiences.

The results allow us to distinguish four levels of marketing in tourism. The first two levels relate to the field of commercial marketing.

1. Marketing of tourism enterprises (tour operators, travel agents), which are the main link in entrepreneurial activity in the tourism sector, harmonizes their capabilities and consumer demands. This process is the provision of services to 
tourists that meet their needs, and the enterprise receives the profit necessary for its development and better satisfaction of consumer needs in the future.

2. Marketing of creators of tourism services (hotels, restaurants, transport organizations, etc.) is a system of comprehensive elaboration of customer's needs and demands in order to organize the provision of services, focused on meeting the needs of specific consumers, and ensuring the most effective forms and methods of service.

The next two levels characterize the field of non-profit marketing in tourism.

1. Marketing of public tourism organizations (unions, associations, etc.) representing and protecting the collective interests of entrepreneurs in the tourism sector is understood as activities aimed at creating, maintaining, or changing a favorable public opinion. Opinion building is essentially marketing management, shifted from the product level to the entire organizational level.

2. Marketing of territories and regions activities are undertaken to create, maintain, or change customer behavior about specific settlements, regions, or countries. Similar activities are carried out by the regulatory and coordination bodies in tourism at the municipal, regional, and national levels.

Thus, various institutional units (state, national, regional, and local tourism authorities, sectoral and inter-sectoral public organizations, and enterprises) are integrated into tourism's marketing system. This raises the problem of vertical coordination of activities necessary to prevent duplication and to achieve optimal consideration, respect, and blending of the interests of customers, enterprises, society, and nature.

\section{CONCLUSIONS}

Several conclusions can be drawn from the above study. Marketing is a system of interconnected techniques and measures that allow the travel company to achieve positive tour services results. Tourism marketing is a system of management and organization of tourism companies to develop new, more efficient types of tourist and excursion services, produce and market them in order to make a profit by improving the quality of the tourist product and taking into account the processes that take place in the world tourism market. Tourism has its specifics; therefore, marketing in tourism also has its uniqueness. The specific nature of marketing in tourism is determined by the tourist product's distinctive characteristics from other consumer goods and services.

Modern marketing of a tourist firm means more than just developing quality services, setting an attractive price on them, and approaching consumers. The travel firm should have a continuous communication relationship with existing and potential customers. Therefore, it is necessary to develop a set of marketing communications to improve the company's efficiency. In a travel company's activity, it is necessary to develop an acceptable pricing policy and use pricing strategies following the travel agency's activities' specifics. Marketing success in tourism depends on a comprehensive analysis of the market, the tourist product, analysis of systems and channels of sale, and product advertising. Tourism enterprises should organize complete marketing services with a qualified staff, which will be engaged in the strategy of improving the company's activities, conduct market research, develop measures to stimulate sales, find the most profitable distribution channels, engage in advertising campaigns, PR and the formation of brand identity.

As discussed earlier, technological advances offer a whole new set of opportunities for marketers. VR stands out, especially in the scope of the ongoing global pandemic and associated travel restrictions and severe tourism impact. VR focuses on the real world and allows the users to experience being in a certain location (Pestek and Sarvan 2020; Kask 2018). A travel company from Uganda - Matoke Tours - offers a VR gorilla trip, where users can stand eye-to-eye with the mighty creature from the comfort of their homes. This helped the company stand out and attract huge tourists' attention to the country. Through VR, Best Western Hotels and Resorts let the customers see and feel their room and fully customize it by their preferences. Australian Qantas Airlines promote by VR all destinations they fly, making the passengers familiar with the places they will stay or planning to visit in the future. The city of Venice (Italy) has VR tours that cover the entire city, and many museums around the globe also adopted VR to let people explore and 
enjoy their collections without leaving the comfort of their homes. Another company The North Face offer to its customers the opportunity to "try-before-you-buy" their products by in-store VR tours to destinations, that best matching the conditions for which the product chosen is intended to be used.

Finally, it should be noted again, that marketing plays a crucial role in shaping the success of all involved in tourism - private entities, organizations, and local and national governments; therefore, up-to-date marketing techniques and tools should be used actively. 


\section{References}

Ali, M, Syamsuddin Amin, and Peri Priansah. 2019. "Marketing Communication Strategy To Improve Tourism Potential." Budapest International Research and Critics Institute-Journal (BIRCI-Journal) 2 (4): 160-66. doi:10.33258/birci.v2i4.575.

Antalova, Maria, Viera Labudová, Volodymyr Chumak, Jarosław Czepczarz, Sabina Wiatkowska, Lukasz Dziarmaga, Oksana Hetman, et al. 2019. "MODERN TECHNOLOGIES OF SOCIETY DEVELOPMENT : Collective Scientific Monograph.” In .

Cuculeski, Nikola, Ilijana Petrovska, and Vasko Cuculeski. 2016. "Sustainable Marketing and Consumers' Preferences in Tourism." European Journal of Tourism, Hospitality and Recreation 7 (2). Walter de Gruyter GmbH: 84-90. doi:10.1515/ejthr-2016-0010.

Dedeoğlu, Bekir Bora, Mathilda van Niekerk, Kemal Gürkan Küçükergin, Marcella De Martino, and Fevzi Okumuş. 2020. "Effect of Social Media Sharing on Destination Brand Awareness and Destination Quality." Journal of Vacation Marketing 26 (1). SAGE Publications Ltd: $\quad 33-56$. doi:10.1177/1356766719858644.

Dudyak, R., O. Berezivska, S. Bugel, and R. Grabowskyi. 2018. "The Marketing of Tourism and Its Characteristics." Visnik L'vivs'kogo Nacional'nogo Agrarnogo Universitetu. Ekonomika APK 25 (December). Lviv National Agrarian University: 133-39. doi:10.31734/economics2018.25.133.

Font, Xavier, and Scott McCabe. 2017. "Sustainability and Marketing in Tourism: Its Contexts, Paradoxes, Approaches, Challenges and Potential." Journal of Sustainable Tourism 25 (7). Routledge: 869-83. doi:10.1080/09669582.2017.1301721.

Gretzel, Ulrike. 2018. "Influencer Marketing in Travel and Tourism." In Social Media for Travel, Tourism and Hospitality: New Perspectives, Practice and Cases, edited by M Sigala and U Gretzel, 147-56. New York: Routledge.

Guttentag, Daniel, Stephen Smith, Luke Potwarka, and Mark Havitz. 2018. "Why
Tourists Choose Airbnb: A MotivationBased Segmentation Study." Journal of Travel Research 57 (3). SAGE Publications Ltd: 342-59. doi:10.1177/0047287517696980.

Kask, Sergey. 2018. "Virtual Reality in Support of Sustainable Tourism: Experiences from Eastern Europe." Tartu: Estonian University of Life Sciences. http://dspace.emu.ee/xmlui/bitstream/han dle/10492/4549/Kask_Sergei_DO2018.p $\mathrm{df}$ ? sequence $=1 \&$ isAllowed $=\mathrm{y}$.

Kim, Woo Hyuk, and Bongsug (Kevin) Chae. 2018. "Understanding the Relationship among Resources, Social Media Use and Hotel Performance: The Case of Twitter Use by Hotels." International Journal of Contemporary Hospitality Management 30 (9). Emerald Group Publishing Ltd.: 2888-2907. doi:10.1108/IJCHM-022017-0085.

Kotler, Milton, Tiger Cao, Sam Wang, and Collen Qiao. 2020. Marketing Strategy in the Digital Age:Applying Kotler's Strategies to Digital Marketing. Marketing Strategy in the Digital Age. 1st ed. World Scientific Publishing Co. Pte. Ltd. doi:10.1142/11737.

Kotler, Philip. 2018. "Why Broadened Marketing Has Enriched Marketing." AMS Review 8 (1-2). Springer Science and Business Media LLC: 20-22. doi:10.1007/s13162-018-0112-4.

Kotler, Philip, John Bowen, and James Makens. 2014. Marketing for Hospitality and Tourism.

Kotler, Phillip, John Bowen, James Makens, and Seyhmus Baloglu. 2017. Marketing for Hospitality and Tourism.

Labanauskaite, Daiva, Mariantonietta Fiore, and Rimantas Stašys. 2020. "Use of EMarketing Tools as Communication Management in the Tourism Industry." Tourism Management Perspectives 34 (April). Elsevier B.V.: 100652. doi:10.1016/j.tmp.2020.100652.

Lim, Weng Marc, Sheau-Fen Yap, and Marian Makkar. 2021. "Home Sharing in Marketing and Tourism at a Tipping Point: What Do We Know, How Do We Know, and Where Should We Be Heading?" Journal of Business Research 122 (January). Elsevier: 534-66. doi:10.1016/j.jbusres.2020.08.051.

Lumsdon, Les. 2016. Marketing for Tourism. 
Marketing for Tourism. Palgrave Macmillan. doi:10.1007/978-1-34921946-9.

Majed Sadq, Zana, and Rebaz Khaleel Khorsheed. 2019. "The Impact of Tourism Marketing in Enhancing Competitive Capabilities." African Journal of Hospitality, Tourism and Leisure 8 https://www.researchgate.net/publication/ 335813376.

Mariani, Marcello, Rodolfo Baggio, Matthias Fuchs, and Wolfram Höepken. 2018. "Business Intelligence and Big Data in Hospitality and Tourism: A Systematic Literature Review." International Journal of Contemporary Hospitality Management. Emerald Group Publishing Ltd. doi:10.1108/IJCHM-07-2017-0461.

news.airbnb.com. 2019. “Airbnb Estimated Direct Economic Impact Exceeds $\$ 100$ Billion in One Year." July 1. https://news.airbnb.com/airbnbestimated-direct-economic-impactexceeds-100-billion-in-one-year/.

Pestek, Almir, and Maida Sarvan. 2020. "Virtual Reality and Modern Tourism." Journal of Tourism Futures. Emerald Group Publishing Ltd. doi:10.1108/JTF01-2020-0004.

Seyfi, Siamak, and C. Michael Hall. 2020. "Sanctions and Tourism: Conceptualisation and Implications for Destination Marketing and Management." Journal of Destination Marketing and Management 15 (March). Elsevier Ltd:
100381.

doi:10.1016/j.jdmm.2019.100381.

Seyfi, Siamak, Colin Michael Hall, and Tan Vo-Thanh. 2020. "Tourism, Peace and Sustainability in Sanctions-Ridden Destinations." Journal of Sustainable Tourism. Routledge doi:10.1080/09669582.2020.1818764.

So, Siu Ian, and Alastair M. Morrison. 2004. "Internet Marketing in Tourism in Asia: An Evaluation of the Performance of East Asian National Tourism Organization Websites." Journal of Hospitality and Leisure Marketing 11 (4). Taylor \& Francis Group: 93-118. doi:10.1300/J150v11n04_07.

Sofronov, Bogdan. 2019. "The Development of Marketing in Tourism Industry." Annals of Spiru Haret University. Economic Series 19 (1). Editura Fundaţiei România de Mâine: 117-27.

Truong, V. Dao, and C. Michael Hall. 2017. "Corporate Social Marketing in Tourism: To Sleep or Not to Sleep with the Enemy?" Journal of Sustainable Tourism $25 \quad$ (7). Routledge: 884-902. doi:10.1080/09669582.2016.1201093.

Zaenal, Achmad Zulkarnaen, Jeni Kamase, and Serlin Serang. 2020. "Analisis Digital Marketing Dan Word of Mouth Sebagai Strategi Promosi Pariwisata." Tata Kelola $7 \quad$ (1): $\quad 62-77 . \quad \mathrm{http}: / /$ pascaumi.ac.id/index.php/tata/article/view/98.

Zuelow, Eric. 2015. A History of Modern Tourism. 1st ed. Palgrave Macmillan. 